\title{
Phylogenetic analysis, based on EPIYA repeats in the cagA gene of Indian Helicobacter pylori, and the implications of sequence variation in tyrosine phosphorylation motifs on determining the clinical outcome
}

\author{
Santosh K. Tiwari ${ }^{1 *}$, Vishwas Sharma ${ }^{1 *}$, Varun Kumar Sharma ${ }^{2 *}$, Manoj Gopi ${ }^{1}$, Saikant $\mathrm{R}^{1}$, Amrita Nandan ${ }^{1}$, \\ Avinash Bardia ${ }^{1}$, Sivaram Gunisetty ${ }^{1}$, Prasanth Katikala ${ }^{3}$, Md. Aejaz Habeeb ${ }^{1}$, Aleem A. Khan ${ }^{1}$ \\ and C.M. Habibullah ${ }^{1}$ \\ ${ }^{1}$ Centre for Liver Research and Diagnostics, Deccan College of Medical Sciences, Kanchanbagh, \\ Hyderabad, Andhra Pradesh, India. \\ ${ }^{2}$ Department of Biotechnology, C.S.J.M. University, Kanpur, Uttar Pradesh, India. \\ ${ }^{3}$ Pharmaceutical Biotechnology Division, A.U. College of Pharmaceutical Sciences, \\ Andhra University, Visakhapatnam, Andhra Pradesh, India.
}

\begin{abstract}
The population of India harbors one of the world's most highly diverse gene pools, owing to the influx of successive waves of immigrants over regular periods in time. Several phylogenetic studies involving mitochondrial DNA and $Y$ chromosomal variation have demonstrated Europeans to have been the first settlers in India. Nevertheless, certain controversy exists, due to the support given to the thesis that colonization was by the Austro-Asiatic group, prior to the Europeans. Thus, the aim was to investigate pre-historic colonization of India by anatomically modern humans, using conserved stretches of five amino acid (EPIYA) sequences in the cagA gene of Helicobacter pylori. Simultaneously, the existence of a pathogenic relationship of tyrosine phosphorylation motifs (TPMs), in 32 H. pylori strains isolated from subjects with several forms of gastric diseases, was also explored. High resolution sequence analysis of the above described genes was performed. The nucleotide sequences obtained were translated into amino acids using MEGA (version 4.0) software for EPIYA. An MJ-Network was constructed for obtaining TPM haplotypes by using NETWORK (version 4.5) software. The findings of the study suggest that Indian H. pyloristrains share a common ancestry with Europeans. No specific association of haplotypes with the outcome of disease was revealed through additional network analysis of TPMs.
\end{abstract}

Key words: Helicobacter pylori, EPIYA motifs, tyrosine phosphorylation motifs, haplotypes, anatomically modern humans.

Received: May 10, 2010; Accepted: October 14, 2010.

\section{Introduction}

The dawn of the $20^{\text {th }}$ century witnessed the discovery of one of the most controversial microorganisms, Helicobacter pylori (H. pylori), responsible for provoking a rupture in contemporary popular medical doctrines, thereby enforcing changes in global conceptions of gastroduodenal disorders (Marshall, 2001). In spite of a general consensus regarding the existence of a causal relationship, there is still disagreement as to how a single bacterium could possibly cause such a variety of disease conditions (Montecucco and Rappuoli, 2001). The apparent paradox suggests that the mere presence of $H$. pylori in the stomach

Send correspondence to Aleem A. Khan. Centre for Liver Research and Diagnostics, Deccan College of Medical Sciences, Kanchanbagh, Hyderabad, 500058 Andhra Pradesh, India. E-mail: aleem_a_khan@ rediffmail.com.

'These authors contributed equally to this work. is insufficient to cause gastric disease, this requiring one or more additional conditions (Crowe, 2005). Apart from several others, $H$. pylori must bear an arsenal of specific virulence-genes such as the cag-pathogenicity island (cagPAI), the vacuolating associated cytotoxin gene A (vacA), the outer membrane protein A (oipA), and blood group antigen binding adhesin ( $b a b \mathrm{~A})$, to be potentially toxigenic (Censini et al., 1996, Cover et al., 1994, Zambon et al., 2003).

Infection by cag-PAI bearing $H$. pylori is recognized as increasing the risk of overt gastric disorders, such as peptic ulceration, gastric cancer and mucosa associated lymphoid tissue (MALT)-lymphoma. Seven genes of this pathogenicity island ( $h p 0524, h p 0525, h p 0527, h p 0528$, $h p 0530, h p 0532$ and $h p 0544$ ) form a typical needle-syringe assembly called the type IV secretion apparatus (T4SS) which translocates 120-145 kDa CagA proteins, either directly into host cells or into the bacterial environment 
(Bourzac and Guillemin, 2005; Christie and Cascales, 2005). During translocation, these undergo tyrosine phosphorylation by several members of the Src family kinases (SFK) such as c-Src, Fyn, Lyn and Yes (Stein et al, 2002). This phosphorylation is reported to occur at specific sites in the CagA protein known as tyrosine phosphorylation motifs (TPMs), characterized by the presence-of a stretch of conserved nucleotide sequences (CNS). Three predicted motifs (TPM-A, TPM-B and TPM-C) have already been reported, based on these CNSs (Odenbreit et al, 2000; Owen et al, 2003). In addition, phosphorylation is also known to occur at the Glu-Pro-Ile-Tyr-Ala (EPIYA) amino acid sequence in TPMs.

The Indian population is widely known for its unique genetic and cultural diversity. Numerous phylogenetic studies based on mitochondrial DNA (mt DNA) and Ychromosomal variation have proved that India played crucial role in the first major colonization by anatomically modern humans (AMH), at least half-a-million years ago (Chaubey et al, 2008). Although, to a certain extent these studies have brought enlightenment to the evolutionary history of AMHs, the number of waves and the periods of migration still remain uncertain and subject to dogmatic views.

Several investigators have used H. pylori as a biological model when studying waves of immigration, owing to co-evolution with its human host (Devi et al, 2007). Coincidentally, the phylogenetic analysis of H. pylori housekeeping gene sequences mirrors the migratory path of AMHs. The number and pattern of the five conserved amino acid sequences (EPIYA) present in the repeat-region of cagA have been well-explored in several phylogenetic studies, with the aim of dissecting the genetic origin of $H$. pylori strains. These have been broadly divided into Western CagA (WSS) and East-Asian CagA (ESS) specific sequences. WSS usually possess an A-B-C pattern characterized by the presence of flanking conserved amino acids, although several other subtypes of this pattern $(A B C$, $\mathrm{ABCC}, \& \mathrm{ABCCC}$ etc) are already known (Higashi et al, 2002). On the contrary, ESS contains a JSR region, previously defined by Yamaoka et al, (1999), besides possessing an EPIYA motif, designated "EPIYA-D, thereby justifying their classification as A-B-D (Azuma et al, 2004). Furthermore, only few studies (Owen et al., 2003) have focused on the status of CagA phosphorylation motifs (TPMs), with no data available from the Indian peninsula. Therefore, the present study attempted to address the prehistoric colonization of humans in India by using the H. pylori genome and, additionally, assess the association of haplotypes of tyrosine phosphorylation motifs with gastroduodenal diseases.

\section{Materials and Methods}

A total of 32 indigenous $H$. pylori strains isolated from individuals with various gastrointestinal disorders, and undergoing treatment at the Department of Gastro- enterology, Deccan College of Medical Sciences, were included for detailed analysis. Information regarding the clinical status and ethnic origin of the study-subjects are given in Table 1. Due, relevant ethical approval for undertaking the study, as well as written informed-consent from the participants prior to inclusion was obtained.

PCR based analysis was applied to the target genes, namely EPIYA motifs and tyrosine phosphorylation motifs-A, B, C, as reported previously, using designated oligonucleotide primers (Karita et al, 2003, Owen et al, 2003). Amplification was performed twice and the sequencing of the amplified products was done with both forward and re-

Table 1 - Details of the H. pylori strains used in the study.

\begin{tabular}{|c|c|c|c|c|c|c|}
\hline $\begin{array}{l}\text { Strains } \\
\text { ID }\end{array}$ & $\begin{array}{c}\text { Disease } \\
\text { type }\end{array}$ & $\begin{array}{l}\text { Ethnic origin } \\
\text { of patients }\end{array}$ & $\begin{array}{l}\text { Type of } \\
\text { EPIYA }\end{array}$ & TPM A & TPM B & TPM C \\
\hline MS 2 & DU & Asian & Western & Present & Present & Absent \\
\hline MS 5 & DU & Asian & Western & Present & Present & Absent \\
\hline MS 8 & DU & Asian & Western & Present & Present & Absent \\
\hline MS 10 & PUD & Asian & Western & Present & Present & Absent \\
\hline MS 11 & DU & Asian & Western & Present & Present & Absent \\
\hline MS 13 & $\mathrm{GC}$ & Asian & Western & Present & Present & Absent \\
\hline MS 14 & DU & Asian & Western & Present & Present & Absent \\
\hline MS 15 & GU & Asian & Western & Present & Present & Absent \\
\hline MS 16 & DU & Asian & Western & Present & Present & Absent \\
\hline MS 17 & DU & Asian & Western & Present & Present & Absent \\
\hline MS 18 & DU & Asian & Western & Present & Present & Absent \\
\hline MS 20 & DU & Asian & Western & Present & Present & Absent \\
\hline MS 23 & DU & Asian & Western & Present & Present & Absent \\
\hline MS 26 & $\mathrm{GC}$ & Asian & Western & Present & Present & Absent \\
\hline MS 28 & DU & Asian & Western & Present & Present & Absent \\
\hline MS 30 & NUD & Asian & Western & Present & Present & Absent \\
\hline MS 40 & GU & Asian & Western & Present & Present & Absent \\
\hline MS 56 & DU & Asian & Western & Present & Present & Absent \\
\hline MS 233 & NUD & Asian & Western & Present & Present & Present \\
\hline MS 401 & NUD & Asian & Western & Present & Present & Absent \\
\hline GC 1 & $\mathrm{GC}$ & Asian & Western & Present & Present & Absent \\
\hline GC 2 & $\mathrm{GC}$ & Asian & Western & Present & Present & Absent \\
\hline GC 3 & $\mathrm{GC}$ & Asian & Western & Present & Present & Absent \\
\hline GC 6 & $\mathrm{GC}$ & Asian & Western & Present & Present & Absent \\
\hline GC 8 & $\mathrm{GC}$ & Asian & Western & Present & Present & Absent \\
\hline GC 11 & $\mathrm{GC}$ & Asian & Western & Present & Present & Absent \\
\hline GC 12 & GC & Asian & Western & Present & Present & Absent \\
\hline GC 16 & $\mathrm{GC}$ & Asian & Western & Present & Present & Absent \\
\hline GC 33 & $\mathrm{GC}$ & Asian & Western & Present & Present & Absent \\
\hline GC 83 & $\mathrm{GC}$ & Asian & Western & Present & Present & Absent \\
\hline GC 123 & $\mathrm{GC}$ & Asian & Western & Present & Present & Absent \\
\hline KL 11 & GC & Asian & Western & Present & Present & Absent \\
\hline
\end{tabular}

DU- duodenal ulcer, PUD- peptic ulcer disease, GU- gastric ulcer, NUDnon-ulcer dyspepsia, GC-gastric cancer. 
verse primers using 5.2.0 Version software from Applied Biosystems (Applied Biosystems, Foster City, USA). For analysis, Quality Values (QVs) were sought from the software itself. The sequences were edited and assembled using AutoAssembler (version 1.4) software (Applied Biosystems) to obtain consensus sequences. Furthermore, in order to minimize ambiguities in the sequences, the set-up was assembled with a minimum overlap of 20 bases and $20 \%$ percent error. The sequences were then translated into amino acid sequences by using MEGA (version 4.0) software (Tamura et al, 2007). Bootstrap phylogeny tests with 500 replications and 1234 seeds were used for this purpose. Finally, they were assigned to the Western or the East Asian specific groups based on the presence of $\mathrm{C}$ - or $\mathrm{D}$ - repeats in the EPIYA motifs, respectively (Figure 1 and Figure S1). Translated amino acid sequences of individual strains were comparatively analyzed using neutral sequences of the J99 H. pylori reference strain. The selection of model parameters was done using Median joining network, based on the Maximum Parsimony method from a set of splits, optimal realizations and reticulograms from a distance matrix. NETWORK (version 4.5) software was used for medianjoining network construction (see Figures S2 a-c) (Saitou and Nei, 1987).

The sequences pertaining to three tyrosine phosphorylation motifs were aligned using AE000511 for TPM A and TPM B, as well as an AF202973 reference sequence for TPM C, the differences being noted and displayed in phylogenetic networks (Figures 2, 3 and 4). The cagA nucleotide sequences containing the tyrosine phosphorylation motifs of the 32 Indian isolates were deposited in GenBank (accession numbers FJ599712-FJ599743). A codon selection test was performed using an online non-synonymous to synonymous substitution ratio calculator (HIV Databases).

\section{Results}

We have analyzed a total 32 strains of $H$. pylori isolated from various clinical backgrounds (Table 1). Se-

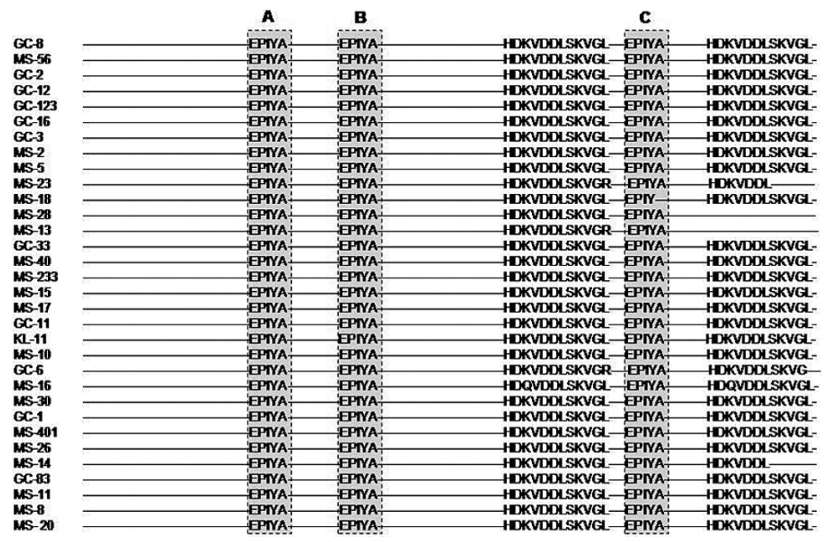

Figure 1 - Deduced amino acid sequences of the 3'repeat region of the cagA gene of 32 Indian strains of $H$. pylori, showing the A-B-C pattern of EPIYA repeats. quence analysis of the repeat region in cagA for assessing EPIYA sequences, revealed the A-B-C pattern to be common in Europeans. Neither the A-B-D pattern (East Asian),

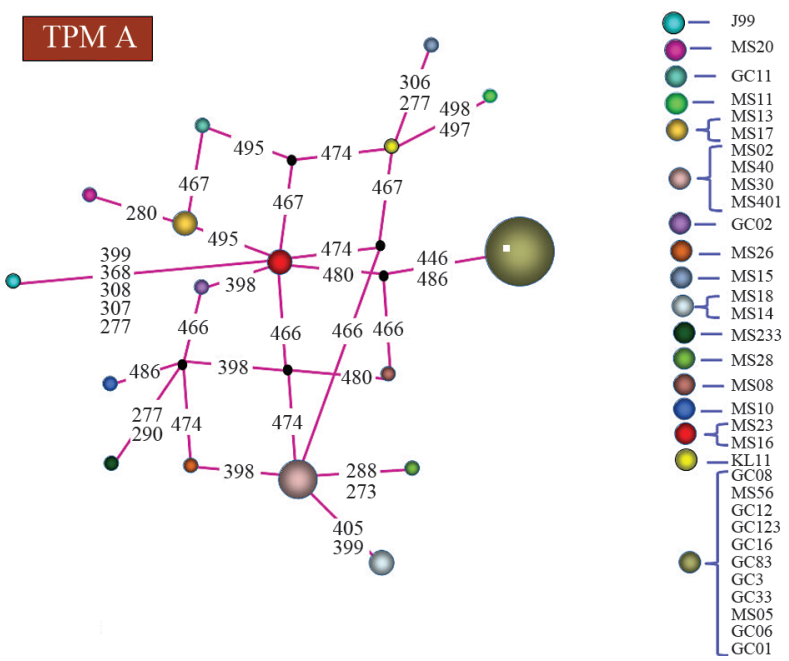

Figure 2 - MJ-network analysis of TPM A showing 16 haplotypes.

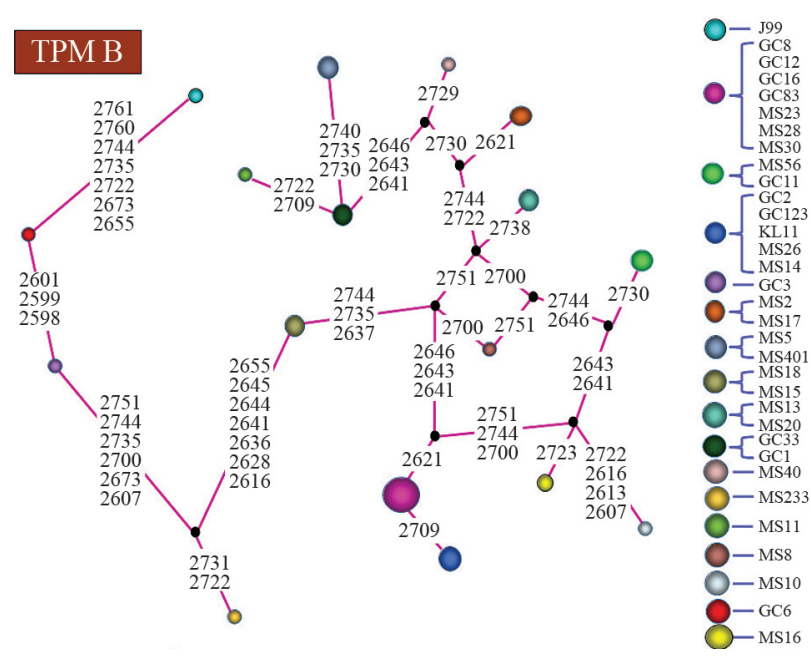

Figure 3 - MJ-network analysis of TPM B showing 16 haplotypes.

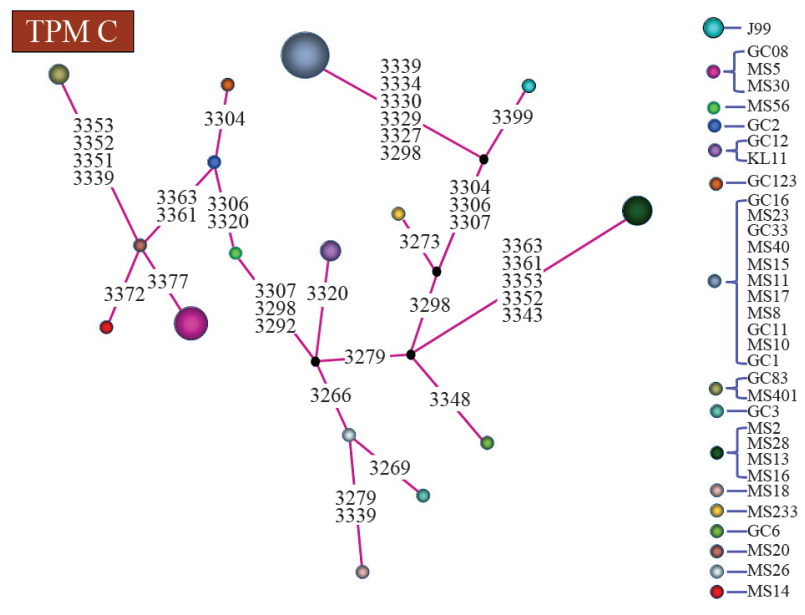

Figure 4 - MJ-network analysis of TPM C showing 15 haplotypes. 
nor any other A-B-C subtypes were present in any of the 32 isolates (Figure 1). The selection test gave a value of 1.4345 , thereby signifying positive selection and co-evolution.

Amplification followed by deduced amino acid sequence analysis at each of the three phosphorylation sites, TPM-A motif, characterized as KFGDQRY, at site 122 in all the strains analyzed (100\%) (Figure S2a). Similarly, the TPM-B motif, originally defined by the amino acid sequence $\mathrm{KNS}(\mathrm{T} / \mathrm{g}) \mathrm{EPIY}$, was found as KNEPIY at site 899 in all the sequences (Figure S2b). Nevertheless, TPM-C, as characterized by KLKDSTKY, was found at site 1029 in only $3.1 \%$ of all the Indian strains screened (Figure S2c).

High resolution analysis of the TPM-A motif revealed 16 distinct haplotypes (Figure 2), those with mutations at site 446-486 (in the strains GC-8, MS-56, GC-12, GC-123, GC-16, GC-83, GC-3, MS-5, GC-33, GC-6, GC1) being predominant. Analysis of the tyrosine phosphorylation motif-B (TPM-B) indicated 16 different haplotypes (Figure 3). Similar high resolution analysis of the tyrosine phosphorylation motif C (TPM-C) showed 15 haplotypes (Figure 4).

Distribution of all the cagA tyrosine phosphorylation motifs was clinically irrelevant, as TPM A and TPM B were found to be present in 100\% of the strains (Figures 2 and 3), whereas TPM C was observed in only 1 (3.1\%) (Figure 4). Similarly different haplotypes of TPM A, TPM B \& TPM C also showed no disease specific association.

\section{Discussion}

The Indian microbial genome is a melting-pot for both evolutionary and pathogenic studies, seeing that it accounts for one of largest gene pools, with more than 1 billion denizens. The A-B-C pattern of EPIYA sequences in Indian strains of $H$. pylori represents a common ancestral root of origin with Europeans, as reported previously (Devi et al., 2007). Although both the time and number of migrations cannot be estimated with software, exploration through various approaches, such as anthropological (Mishra, 2001), historical (Kennedy et al, 1987), mitochondrial DNA and Y-chromosomal studies, have demonstrated that the Austro-Asiatic (AA) tribal groups were the first settlers of India (Majumder, 2001; Metspalu et al., 2004; Thangaraj et al., 2005; Kumar et al., 2007; Chaubey et al., 2008). Furthermore, this microbe is also known to have co-evolved with anatomically modern humans $(\mathrm{AMH})$ in Africa ( 50$70 \mathrm{kYa}$ ) (Linz et al., 2007). On considering the above hypothesis, one can say that AA language speakers would have been the first to introduce $H$. pylori into India, and not Indo-European, as previously reported (Devi et al, 2007). In fact Indo-Europeans played a major role in the later-day colonization and expansion of this bacterium during the Neolithic era of the Stone age (Mishra, 2001).

The AA family is broadly divided into two subfamilies, i.e. the Mundari and the Mon-Khmer (Ethnologue web-site). The former, found exclusively on the Indian sub-continent, are considered to have been traditional hunters, their feeding on uncooked food having been the most probable acquisition-route of $H$. pylori in humans ( 50-70 kYa) (Mishra, 2001).

Although tyrosine phosphorylation reportedly occurs at any of the three motifs (TPM-A, TPM-B and TPM-C), detailed sequence-analysis of individual distribution proved to be of no prognostic value, as no site-specific mutation in any of the three tyrosine phosphorylation motifs was observed to be directly associated with disease status (Figure S2 a, b, c), thereby implying the outcome to be TPM-independent. The presence of KNEPIY in the place of $\mathrm{KNS}(\mathrm{T} / \mathrm{g}) \mathrm{EPIY}$ at site 899 in the strains studied, requires further investigation on large number of samples from different geographical locations of the Indian subcontinent (Figure 3). These observations are in absolute conformity with those reported by Owen et al, (2003), who demonstrated there to be no association of the number and type of TPMs present, with the severity of the disease. Nonetheless, they reported relatively lower frequencies in all the three TPMs (Owen et al., 2003) than was the case in the present study. Another study from Costa Rica (Occhialini et al, 2001), reported relative frequencies of $100 \%$ and $58 \%$ for TPM A and B, respectively, but were unable to detect the TPM C motif in any of the strains studied. The reason for such discordance between studies is unclear thereby warranting detailed investigation of large clinical isolates from several geographical areas. Although, according to MJ-networks, TPM genes may not be pathogenetically relevant, an attempt was made to understand whether haplotypes play any specific, associated role in altering the outcome of a disease. Our high-resolution study based on MJ networks in $32 \mathrm{H}$. pylori strains showed this was not so.

In conclusion, the results of the present investigation support the dogma of European roots for Indian H. pylori. Nevertheless, their first introduction to the Indian subcontinent by Indo-Europeans remains a highly contentious issue, with sufficient reports favoring Austro-Asiatic speakers as having been the first settlers. Finally, sequence-analysis of the cagA tyrosine phosphorylation motifs revealed no association with their clinical presentation, as evident from frequency distribution and MJ-network analysis, thereby implying that the nature and severity of gastroduodenal diseases are independent of tyrosine phosphorylation motifs.

\section{Acknowledgments}

The authors would like to acknowledge the kind help of Dr. Mahesh Dharne, National Centre for Cell Sciences, Pune, INDIA in sequencing clinical samples.

\section{References}

Azuma T, Yamazaki S, Yamakawa A, Ohtani M, Muramatsu A, Suto H, Ito Y, Dojo M, Yamazaki Y, Kuriyama M, et al. 
(2004) Association between diversity in the Src Homology 2 domain-containing tyrosine phosphatase binding site of Helicobacter pylori CagA protein and gastric atrophy and cancer. J Infect Dis 189:820-827.

Bourzac KM and Guillemin K (2005) Helicobacter pylori-host cell interactions mediated by type IV secretion. Cell Microbiol 7:911-919.

Censini S, Lange C, Xiang C, Crabtree P, Giara P, Borodovsky M, Rappuoli R and Covacci A (1996) cag, a pathogenicity island of Helicobacter pylori encodes type I-specific and disease-associated virulence factors. Proc Natl Acad Sci USA 93:14648-14653.

Chaubey G, Karmin M, Metspalu E, Metspalu M, Selvi-Rani D, Singh VK, Parik J, Solnik A, Naidu BP, Kumar A, et al. (2008) Phylogeography of mtDNA haplogroup R7 in the Indian peninsula. BMC Evol Biol 8:e227.

Christie PJ and Cascales E (2005) Structural and dynamic properties of bacterial type IV secretion systems. Mol Membr Biol 22:51-61.

Cover TL, Tummuru MK, Cao P, Thompson A and Blaser MJ (1994) Divergence of genetic sequences for the vacuolating cytotoxin among Helicobacter pylori strains. J Biol Chem 269:10566-10573.

Crowe SE (2005) Helicobacter infection, chronic inflammation, and the development of malignancy. Curr Opin Gastroenterol 21:32-38.

Devi SM, Ahmed I, Francalacci P, Hussain MA, Akhter Y, Alvi A, Sechi LA, Mégraud F and Ahmed N (2007) Ancestral European roots of Helicobacter pylori in India. BMC Genomics 8:e184.

Higashi H, Tsutsumi R, Fujita A, Yamazaki S, Asaka M, Azuma T and Hatakeyama M (2002) Biological activity of the Helicobacter pylori virulence factor CagA is determined by variation in the tyrosine phosphorylation sites. Proc Natl Acad Sci USA 99:14428-14433.

Karita M, Matsumoto S and Kamei T (2003) The size of cagA based on repeat sequence has the responsibility of the location of Helicobacter pylori in the gastric mucus and the degree of gastric mucosal inflammation. Microbiol Immunol 47:619-630.

Kennedy KA, Deraniyagala SU, Roertgen WJ, Chiment J and Sisotell T (1987) Upper Pleistocene fossil hominids from Sri Lanka. Am J Phys Anthrop 72:441-461.

Kumar V, Reddy AN, Babu JP, Rao TN, Langstieh BT, Thangaraj K, Reddy AG, Singh L and Reddy BM (2007) Y-chromosome evidence suggests a common paternal heritage of Austro-Asiatic populations. BMC Evol Biol 7:e47.

Linz B, Balloux F, Moodley Y, Manica A, Liu H, Roumagnac P, Falush D, Stamer C, Prugnolle F, van der Merwe SW, et al. (2007) An African origin for the intimate association between humans and Helicobacter pylori. Nature 445:915918.

Majumder PP (2001) Ethnic population of India as seen from an evolutionary perspective. J Biosci 26:533-545.

Marshall BJ (2001) One hundred years of discovery and rediscovery of Helicobacter pylori and its association with peptic ulcer disease. In: Mobley HLT, Mendz GL and Hazell SL (eds) Helicobacter pylori: Physiology and Genetics. American Society of Microbiology, Washington DC, pp 178-186.
Metspalu M, Kivisild T, Metspalu E, Parik J, Hudjashov G, Kaldma K, Serk P, Karmin M, Behar DM, Gilbert MTP, et al. (2004) Most of the extant mtDNA boundaries in South and Southwest Asia were likely shaped during the initial settlement of Eurasia by anatomically modern humans. BMC Genetics 5:e26

Mishra VN (2001) Prehistoric human colonization of India. J Biosci 26:491-531.

Montecucco C and Rappuoli R (2001) Living dangerously: How Helicobacter pylori survives in the human stomach. Nat Rev Mol Cell Biol 2:457-466.

Occhialini A, Marais A, Urdaci M, Sierra R, Munoz N, Covacci A and Megraud F (2001) Composition and gene expression of the cag pathogenicity island in Helicobacter pylori strains from gastric carcinoma and gastritis patients in Costa Rica. Infect Immun 6:1902-1908.

Odenbreit S, Püls J, Sedlmaier B, Gerland E, Fischer W and Hass R (2000) Translocation of Helicobacter pylori CagA into gastric epithelial cells by type IV secretion. Science 287:1497-1500.

Owen RJ, Sharp SI, Chisholm SA and Rijpkema S (2003) Identification of cagA tyrosine phosphorylation DNA motifs in Helicobacter pylori isolates from peptic ulcer patients by novel PCR-restriction fragment length polymorphism and real-time fluorescence PCR assays. J Clin Microbiol 41:3112-3118.

Saitou N and Nei M (1987) The neighbor-joining method: A new method for reconstructing phylogenetic trees. Mol Biol Evol 4:406-425.

Stein M, Bagnoli F, Halenbeck R, Rappuoli R, Fantl WJ and Covacci A (2002) c-Src/Lyn kinases activate Helicobacter pylori CagA through tyrosine phosphorylation of the EPIYA motifs. Mol Microbiol 43:971-980.

Tamura K, Dudley J, Nei M and Kumar S (2007) MEGA4: Molecular Evolutionary Genetics Analysis (MEGA) software v. 4.0. The neighbor-joining method: A new method for reconstructing phylogenetic trees. Mol Biol Evol 24:1596-1599.

Thangaraj K, Sridhar V, Kivisild T, Reddy AG, Chaubey G, Singh VK, Kaur S, Agarawal P, Rai A, Gupta J, et al. (2005) Different population histories of the Mundari-and MonKhmer-speaking Austro-Asiatic tribes inferred from the mtDNA 9-bp deletion/insertion polymorphism in Indian populations. Hum Genet 116:507-517.

Yamaoka Y, El-Zimaity HM, Gutierrez O, Figura N, Kim JK, Kodama T, Kashima K and Graham DY (1999) Relationship between the cagA 3' repeat region of Helicobacter pylori, gastric histology, and susceptibility to low $\mathrm{pH}$. Gastroenterology 117:342-349.

Zambon CF, Navaglia F, Basso D, Rugge M and Plebani M (2003) Helicobacter pylori babA2, cagA, and s1 vacA genes work synergistically in causing intestinal metaplasia. J Clin Pathol 56:287-291.

\section{Internet Resources}

Ethnologue web-site, http://www.ethnologue.com/show_family.asp?subid $=271-16$.

NETWORK v. 4.5 software, http://www.fluxusengineering.com (February 7, 2010). 
HIV Databases, non-synonymous to synonymous substitution ratio calculator, http://www.hiv.lanl.gov www.fluxusengineering.com (March 30, 2010).

\section{Supplementary Material}

The following online material is available for this article

Figure S1 - Deduced amino acid sequences of 3' repeat region of cagA gene from 32 Indian strains of $H$. pylori showing EPIYA sequences.
Figure S2 - Deduced amino acid sequence of partial cagA gene of $H$. pylori showing (a) tyrosine phosphorylation motif A (TPM A), (b) tyrosine phosphorylation motif B (TPM B), and (c) tyrosine phosphorylation motif C (TPM C).

This material is available as part of the online article from http://www.scielo.br/gmb.

Associate Editor: Luís Carlos de Souza Ferreira

License information: This is an open-access article distributed under the terms of the Creative Commons Attribution License, which permits unrestricted use, distribution, and reproduction in any medium, provided the original work is properly cited. 
Figure S1: Deduced amino acid sequences of 3' repeat region of cagA gene from 32 Indian strains of $H$. pylori showing EPIYA sequences.

GC-8

*IF**IHGKNKDFSKAEETLKALKGSVKDLGINPEWISKVENLNAALNEFKNGKNKDFSKVTQAKSDLENSVKDVIINQKI TDKVDNLNQAVSVAKAMGDFSRVEQALADLKNFSKDQLAQQAQKNEDFNTGKKSEIYQSVKNGVNGTLVGNGLSQ AEATTLSKNFSDIRKELNAKLGNFNNNNNNGLKNEPIYAKVNKKKAGQAASPEEPIYAQVAKKVNAKIDRLNQIASGL GGVGQAAGFPLKKHDKVDDLSKVGLSASPEPIYATIDDLGGPFPLKRHDKVDDLSKVGL-

\section{MS-56}

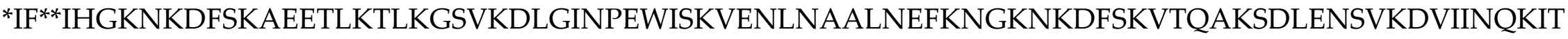
DKVDNLSSAVSVAKATGDFSRVEQALADLKNFSKDQLAQQAQKNEDFNTGKNSELYQSVKNGVNGTLVGNGLSQAE ATTLSKNFSDIKKELNEKFKNFNNNNNNGLKNEPIYAKVNKKKTGEVASLEEPIYAQVAKKVNAKIDRLNQIASGLGG VGQAAGFPLKRHDKVDDLSKVGLSASPEPIYATIDDLGGPFPLKRHDKVDDLSKVGL-

\section{GC-2}

*IF**IHGKNKDFSKAEETLKALKGSVKDLGINPEWISKVENLNAALNEFKNGKNKDFSKVTQAKSDLENSVKDVIINQKI TDKVDNLNQAVSVAKAMGDFSRVEQALADLKNFSKDQLAQQAQKNEDFNTGKKSEIYQSVKNGVNGTLVGNGLSQ AEATTLSKNFSDIRKELNAKLGNFNNNNNNGLKNEPIYAKVNKKKAGQTASPEEPIYAQVAKKVNAKIDRLNQIASGL GGVGQAAGFPLKKHDKVDDLSKVGLSASPEPIYATIDDLGGPFPLKRHDKVDDLSKVGL-

\section{GC-12}

*IF**IHGKNKDFSKAEETLKALKGSVKDLGISPEWISKVENLNAALNEFKNGKNKDFSKVTQAKSDLENSVKDVIINQKIT DKVDNLNQAVSVAKATGDFSRVEQALADLKNFSKEQLAQQAQKNEDFNTGKNSALYQSVKNGVNGTLVGNGLSKA EATTLSKNFSDIKKELNAKLGNFNNNNNNGLKNEPIYAKVNKKKTQGQAASLEEPIYAQVAKKVNAKIDRLNQIASGL GGVGQAAGFPLKKHDKVDDLSKVGLSASPEPIYATIDDLGGPFPLKRHDKVDDLSKVGL 


\section{GC-123}

*IF**IHGKNKDFSKAEETLKALKGSVEDLGINPEWISKVENLNAALNEFKNGKNKDFSKVTQAKSDLENSVKDVIINQKI TDKVDNLNQAVSVAKATGDFSRVEQALADLKNFSKDQLAQQAQKNESFNAGKKSEIYQSVKNGVNGTLVGNGLSKA EATTLSKNFSDIKKELNAKLGNFNNNNNNGLKNEPIYAKVNKKKAGQVASLEEPIYAQVAKKVNAKIDQLNQAASGL GGVGQAGFPLKRHDKVDDLSKVGLSANPEPIYATIDDLGGPFPLKRHDKVDDLSKVGL--

\section{GC-16}

*IF**IHGKNKDFSKAEETLKALKGSVKDLGINPEWISKVENLNAALNEFKNGKNKDFSKVTQAKSDLENSVKDVIINQKI TDKVDNLNQAVSVAKAMGDFSRVEQALADLKNFSKDQLAQQAQKNEDFNTGKKSEIYQSVKNGVNGTLVGNGLSQ AEATTLSKNFSDIRKELNAKLGNFNNNNNNGLKNEPIYAKVNKKKAGQAASPEEPIYAQVAKKVNAKIDRLNQIASGL GGVGQVAGFPLKKHDKVDDLSKVGLSASPEPIYATIDDLGGPFPLKRHDKVDDLSKVGL-

\section{GC-3}

${ }^{*} I^{* *}$ IHGKNKDFSKAEETLKALKGSVKDLGINPEWISKVENLNAALNEFKNGKNKDFSKVTQAKSDLENSVKDVIINQKI TDKVDNLNQAVSVAKAMGDFSRVEQALADLKNFSKDQLAQQAQKNEDFNTGKKSEIYQSVKNGVNGTLVGNGLSQ AEATTLSKNFSDIRKELNAKLGNFNNNNNNGLKNEPIYAKVNKKKAGQTASPEEPIYAQVAKKVNAKIDRLNQIASGL GGVGQVAGFPLKKHDKVDDLSKVGLSASPEPIYATIDDLGGPFPLKRHDKVDDLSKVGL-

\section{MS-2}

*IF**IHDKNKDFSKAEETLKALKGSVKDLGISPEWISKVENLNAALNEFKNGKNKDFSKVTQAKSDLENSVKDVIINQKIT DKVDNLNQAVSVAKATGDFSRVEQALADLKNFSKDQLAQQAQKNESFNTGKNSALYQSVKNGVNGTLVGNGLSKAE ATTLSKNFSDIKKELNAKLGNFNNNNNGLKNEPIYAKVNKKKAGQADSPEEPIYAQVAKKVNAKIDRLNQAASGFGG VNPAGFPLKRHDKVDDLSKVGLSASPEPIYATIDDLGGPFPLKRHDKVDDLSKVGL---

\section{MS-5}

*IF*FKNGKNKDFSKAEETLKALKGSVKDLGINPEWISKVENLNAALNEFKNGKNKDFSKVTQAKSDLENSVKDVIINQK ITDKVDNLNQAVSVAKAMGDFSRVEQALADLKNFSKDQLAQQAQKNEDFNTGKKSEIYQSVKNGVNGTLVGNGLSQ AEATTLSKNFSDIRKELNAKLGNFNNNNNNGLKNEPIYAKVNKKKAGQTASPEEPIYAQVAKKVNAKIDRLNQIASGL GGVGQVAGFPLKKHDKVDDLSKVGLSASPEPIYATIDDLGGPFPLKRHDKVDDLSKVGL- 
MS-23

SFDEFKNGKNKDFSKAEETLKALKGSVKDLGISPEWISKVENLNATLNEFKNGKNKDFSKVTQAKSDLENSVKDVIINQ KITDKVDNLNQAVSVAKTTGDFSRVEQALADLNNFSKGQLAQQAQKNESFNAGKKSEIYQSVKNGVNGTLVGNGLSQ AEATTLSKNFSDIKKELNAKLGNFNNNNNGLKNEPIYAKVNKKKAGQAASHEEPIYAQVAKKVNAKIDRLNQIARGL GGVGQAAGFPLKRHDKVDDLSKVGRSVSPEPIYATIDDLGGPFPLKRHDKVDDL?

\section{MS-18}

SFDEFKNGKNKDFSKAEETLKTLKGSVKDLGINPEWISKVENLNAALNEFKNGKNKDFSKVTQAKSDLENSVKDVIINQ KITDKVDNLSSAVSVAKATGDFSRVEQALADLKNFSKEQLAQQAQKNEDFNTGKNSALYQSVKNGVNGTLVGNGLSK AEATTLSKNFSDIKKELNAKLGNFNNNNNNGLKNEPIYAKVNKKKTGQIAGLEEPIYAQVAKKVNAKIDRLNQIASGL GGLGQAAGFPLKKHDKVDDLSKVGLSASPEPIYSTMDDLGGPFPLKRHDKVDDLSKVGL-

\section{MS-28}

SFDEFKNGKNKDFSKAEETLKALKGSVKDLGINPEWISKVENLNAALNEFKNGKNKDFSKVTQAKSDLENSVKDVIINQ KITDKVDNLNQAVSVAKAMGDFSRVEQALADLKNFSKDQLAQQAQKNEDFNTGKKSEIYQSVKNGVNGTLVGNGLS QAEATTLSKNFSDIRKELNAKLGNFNNNNNNGLKNEPIYAKVNKKKAGQAASPEEPIYAQVAKKVNAKIDRLNQIAS GLGGVGQVAGFPLKKHDKVDDLSKVGLSASPEPIYATIDDLGGPFPLKRHDN**SQ*GRA?-

\section{MS-13}

SFDEFKNGKNKDFSKAEETLKALKGSVKDLGISPEWISKVENLNATLNEFKNGKNKDFSKVTQAKSDLENSVKDVIINQ KITDKVDNLNRAVSVAKATGDFSRVEQALADLNNFSKGQLAQQAQKNESFNAGKKSEIYQSVKNGVNGTLVGNGLSQ AEATTLSKNFSDIKKELNAKLGNFNNNNNGLKNEPIYAKVNKKKAGQAASHEEPIYAQVAKKVNAKIDRLNQIARGL GCVGQAAGFPLKRHDKVDDLSKVGRSVSPEPIYATIDDLGGPFPLKRHDKVDDLSKVG?--

GC-33

SFDEFKNGKNKDFSKAEETLKALKGSMKDLGISPEWISKVENLNAALNEFKNGKNKDFSKVTQAKSDLENSVKDVIINQ KITDKVDNLNQAVSVAKATGDFSRVEQALADLKNFSKEQLAQQAQKNESFNAGKKSEIYQSVKNGVNGTLVGNGLSG IEATALAKNFSDIKKELNEKFKNFNNNNNNGLKNEPIYAKVNKKKAGQAASHEEPIYAQVAKKVNAKIDQLNQAASG FGGVNQAGFPLKRHDKVDDLSKVGLSASPEPIYATIDDLGGPFPLKRHDKVDDLSKVGL-- 
MS-40

SFDEFKNGKNKDFSKAEETLKTLKGSVKDLGINPEWISKVENLNAALNEFKNGKNKDFSKVTQAKSDLENSVKDVIINQ KVTDKVDNLSSAVSVAKATGDFSRVEQALADLKNFSKEQLAQQAQKNEDFNTGKNSALYQSVKNGVNGTLVGNGLS KAEATTLSKNFSDIKKELNAKLGNFNNNNNNGLKNEPIYAKVNKKKVGQAASHEEPIYAQVAKKVNAKIDRLNQIAS GLGGVGQAAGYPLKRHDKVDDLSKVGLSASPEPIYATIDDLGGPFPLKRHDKVDDLSKVGL-

\section{MS-233}

SFDEFKNGKNKDFSKAEETLKALKGSVKDLGINPEWISKVENLNAALNEFKNGKNKDFSKVTQAKSDLENSVKDVIINQ KITDKVDNLNQAVSVAKAMGDFSRVEQALADLKNFSKDQLAQQAQKNEDFNTGKKSEIYQSVKNGVNGTLVGNGLS QAEATTLSKNFSDIRKELNAKLGNFNNNNNNGLKNEPIYAKVNKKKAGQAASPEEPIYAQVAKKVNAKIDRLNQIAS GLGGVGQAAGFPLKKHDKVDDLSKVGLSASPEPIYATIDDLGGPFPLKRHDKVDDLSKVGL-

\section{MS-15}

SFDEFKNDKNKDFSKAEETLKALKGSVKDLGISPEWISKVENLNAALNEFKNGKNKDFSKVTQAKSDLENSVKDVIINQ KITDKVDNLNQAVSVAKATGDFSRVEQALADLKNFSKDQLAQQAQKNESFNTGKNSALYQSVKNGVNGTLVGNGLS KAEATTLSKNFSDIKKELNAKLGNFNNNNNGLKNEPIYAKVNKKKAGQADSPEEPIYAQVAKKVNAKIDRLNQAASG FGGVNPAGFPLKRHDKVDDLSKVGLSASPEPIYATIDDLGGPFPLKRHDKVDDLSKVGL---

\section{MS-17}

SFDEFKNGKNKDFSKAEETLKALKGSVKDLGINPEWISKVENLNAALNEFKNGKNKDFSKVTQAKSDLENSVKDVIINQ KITDKVDNLNQAVSVAKAMGDFSRVEQALADLKNFSKDQLAQQAQKNEDFNTGKKSEIYQSVKNGVNGTLVGNGLS QAEATTLSKNFSDIRKELNAKLGNFNNNNNNGLKNEPIYAKVNKKKAGQTASPEEPIYAQVAKKVNAKIDRLNQIASG LGGVGQAAGFPLKKHDKVDDLSKVGLSASPEPIYATIDDLGGPFPLKRHDKVDDLSKVGL-

GC-11

GSVKDLGINPEWISKVENLNAALNEFKNGKNKDFSKVTQAKSDLENSVKDVIINQKITDKVDNLNQAVSVAKAMGDFS MVEQALADLKNFSKDQLAQQAQKNEDFNTGKKSEIYQSVKNGVNGTLVGNGLSQAEATTLSKNFSDIRKELNAKLGN FNNNNNNGLKNEPIYAKVNKKKAGQAASPEEPIYAQVAKKVNAKIDQLNQIASGLGGVGQVAGFPLKKHDKVDDLS KVGLSASPEPIYATIDDLGGPFPLKRHDKVDDLSKVGL- 


\section{KL-11}

SFDEFKNGKNKDFSKAEETLKTLKGSVKDLGINPEWISKVENLNAALNEFKNGKNKDFSKVTQAKSDLENSVKDVIINQ KITDKVDNLSSAVSVAKATGDFSRVEQALADLKNFSKEQLAQQAQKNEDFNTGKNSALYQSVKNGVNGTLVGNGLSK AEATTLSKNFSDIKKELNAKLGNFNNNNNNGLKNEPIYAKVNKKKTGQIAGLEEPIYAQVAKKVNAKIDRLNQIASGL GGVGQAAGFPLKKHDKVDDLSKVGLSASPEPIYATIDDLGGPFPLKRHDKVDDLSKVGL-

\section{MS-10}

SFDEFKNGKNKDFSKAEETLKTLKGSVKDLGINPEWISKVENLNAALNEFKNGKNKDFSKVTQAKSDLENSVKDVIINQ KITDKVDNLSSAVSVAKATGDFSRVEQALADLKNFSKEQLAQQAQKNEDFNTGKNSALYQSVKNGVNGTLVGNGLSK AEATTLSKNFSDIKKELNAKLGNFNNNNNNGLKNEPIYAKVNKKKTGQVAGLEEPIYAQVAKKVNAKIDRLNQIASGL GGVGQAAGFPLKKHDKVDDLSKVGLSASPEPIYATIDDLGGPFPLKRHDKVDDLSKVGL-

\section{GC-6}

SFDEFKNGKNKDFSKAEETLKALKGSVKDLGINPEWISKVENLNAALNEFKNGKNKDFSKVTQAKSDLENSVKDVIINQ KVTDKVDNLSSAVSMAKATGDFSRVNQALADLNNFSKEQLAQQAQKNEDFNTGKNSALYQSVKNGVNETLVGNGLS KAEATTLSKNFSDIKKELNAKLGNFNNNNNNGLKNEPIYAKVNKKKAGQAASLEEPIYAQVAKKVNAKIDQLNQAAS GLGGVGQAGFPLKRHDKVDDLSKVGRSVSPEPIYATIDDLGGPFPLKRHDKVDDLSKVGF--

\section{MS-16}

SFDEFKNGKNKDFSKTEETLKTLKGSVKDLGINPEWISKVENLNAALNEFKNGKNKDFSKVTQAKSDLENSVKDVIINQ KITDKVDNLNQAVSVAKATGDFSRVEQALVDLKNFSKEQLAQQAQKNEDFNTGKNSALYQSVKNGMNGTLVGNGLS KAEATTLSKNFSDIKKELNAKLGNFNNNNNNGLKNEPIYAKVNKKKTQGQTASLEEPIYAQVAKKVNAKIDRLNQIAS GLGGVGQAAGFPLKKHDQVDDLSKVGLSASPEPIYATIDDLGGPFPLKRHDQVDDLSKVGL 
MS-30

SFDEFKNGKNKDFSKAEETLKALKGSVKDLGINPEWISKVENLNAALNEFKNGKNKDFSKVTQAKNDLENSVKDVIIN QKITDKVDNLNQAVSVAKATGDFSGVEQALADLKNFSKEQLAQQAQKNEDFNAGKNSALYQSVKNGVNGTLVGNG LSKAEATTLSKNFSDIRKELNAKLGNFNNNNNNGLKNEPIYAKVNKKKAGQAASPEEPIYAQVAKKVNAKIDRLNQIA SGLGGVGKAAGFPLKRHDKVDDLSKVGLSASPEPIYATIDDLGGPFPLKRHDKVDDLSKVGL-

\section{GC-1}

SFDEFKNGKNKDFSKAEETLKALKGSVEDLGINPEWISKVENLNAALNEFKNGKNKDFSKVTQAKSDLENSVKDVIINQ KITDKVDNLNQAVSVAKATGDFSRVEQALADLKNFSKDQLAQQAQKNESFNAGKKSEIYQSVKNGVNGTLVGNGLSK AEATTLSKNFSDIKKELNAKLGNFNNNNNNGLKNEPIYAKVNKKKAGQVASLEEPIYAQVAKKVNAKIDQLNQAASG LGGVGPAGFPLKRHDKVDDLSKVGLSANPEPIYATIDDLGGPFPLKRHDKVDDLSKVGL--

\section{MS-401}

SFDEFKNGKNKDFSKAEETLKALKGSVKDLGINPEWISKVENLNTALNEFKNGKNKDFSKVTQAKSDLENSVKDVIINQ KITDKVDNLNQAVSVAKATDDFSMVEQALADLKNFSKEQLAQQAQKNESFNAGKKSEIYQSVKNGVNGTLVGNGLS QAEATTLSKNFSDIKKELNAKLGNFNNNNNNGLKNEPIYAKVNKKKTEQAASLEEPIYAQVAKKVNAKIDQLNQAAS GLGGVNQAGFPLKRHDKVDDLSKVGLSASPEPIYATIDDLGGPFPLKKHDKVDDLSKVGL--

\section{MS-26}

SFDEFKNGKNKDFSKAEETLKALKGSVKDLGINPEWISKVENLNAALNEFKNGKNKDFSKVTQAKSDLENSVKDVIINQ KITDKVDNLNQAVSVAKAMGDFSRVEQALADLKNFSKDQLAQQAQKNEDFNTGKKSEIYQSVKNGVNGTLVGNGLS QAEATTLSKNFSDIRKELNAKLGNFNNNNNNGLKNEPIYAKVNKKKAGQAASPEEPIYAQVAKKVNAKIDRLNQIAS GLGGVGQAAGFLLKKHDKVDDLSKVGLSASPEPIYAKIYDLGGPFPLKRHDKVDDLSKVGL-

\section{MS-14}

SFDEFKNGKNKDFSKAEETLKALKGSVKDLGINPEWISKVENLNAALNEFKNGKNKDFSKVTQAKSDLENSVKDVIINQ KITDKVDNLNQAVSVAKAMGDFSRVEQALADLKNFSKDQLAQQAQKNENFNAGKKSEIYQSVKNGVNGTLVGNGLS QAEATTLSKNFSDIRKELNAKLGNFNNNNNNGLKNEPIYAKVNKKKAGQAASPEEPIYAQVAKKVNAKIDQLNQAAS GLGGVGQAGFPLKKHDKVDDLSKVGLSASPEPIYATIDDLGGPFPLKRHDKVDDL?- 
GC-83

*IF**IHGKNKDFSKAEETLKALKGSVKDLGINPEWISKVENLNAALNEFKNGKNKDFSKVTQAKSDLENSVKDVIINQKI TDKVDNLNQAVSVAKAMGDFSRVEQALADLKNFSKDQLAQQAQKNEDFNTGKKSEIYQSVKNGVNGTLVGNGLSQ AEATTLSKNFSDIRKELNAKLGNFNNNNNNGLKNEPIYAKVNKKKAGQTASPEEPIYAQVAKKVNAKIDRLNQIASGL GGVGQAAGFPLKKHDKVDDLSKVGLSASPEPIYATIDDLGGPFPLKRHDKVDDLSKVG

\section{MS-11}

*IF**IHGKNKDFSKAEETLKALKGSVKDLGINPEWISKVENLNAALNEFKNGKNKDFSKVTQAKSDLENSVKDVIINQKI TDKVDNLNQAVSVAKAMGDFSRVEQALADLKNFSKDQLAQQAQKNEDFNTGKKSEIYQSVKNGVNGTLVGNGLSQ AEATTLSKNFSDIRKELNAKLGNFNNNNNNGLKNEPIYAKVNKKKAGQTASPEEPIYAQVAKKVNAKIDRLNQIASGL GGVGQAAGFPLKKHDKVDDLSKVGLSASPEPIYATIDDLGGPFPLKRHDKVDDLSKVG--

\section{MS-8}

*IHGKNKDFSKAEETLKALKGSVKDLGINPEWISKVENLNAALNEFKNGKNKDFSKVTQAKSDLENSVKDVIINQKITDK VDNLNQAVSVAKAMGDFSRVEQALADLKNFSKDQLAQQAQKNEDFNTGKKSEIYQSVKNGVNGTLVGNGLSQAEAT TLSKNFSDIRKELNAKLGNFNNNNNNGLKNEPIYAKVNKKKAGQTASPEEPIYAQVAKKVNAKIDRLNQIASGLGGVG QAAGFPLKKHDKVDDLSKVGLSASPEPIYATIDDLGGPFPLKRHDKVDDLSKVG

\section{MS-20}

*IF**IHGKNKDFSKAEETLKALKGSVKDLGINPEWISKVENLNAALNEFKNGKNKDFSKVTQAKSDLENSVKDVIINQKI TDKVDNLNQAVSVAKAMGDFSRVEQALADLKNFSKDQLAQQAQKNEDFNTGKKSEIYQSVKNGVNGTLVGNGLSQ AEATTLSKNFSDIRKELNAKLGNFNNNNNNGLKNEPIYAKVNKKKAGQTASPEEPIYAQVAKKVNAKIDRLNQIASGL GGVGQAAGFPLKKHDKVDDLSKVGLSASPEPIYATIDDLGGPFPLKRHDKVDDLSKVG 

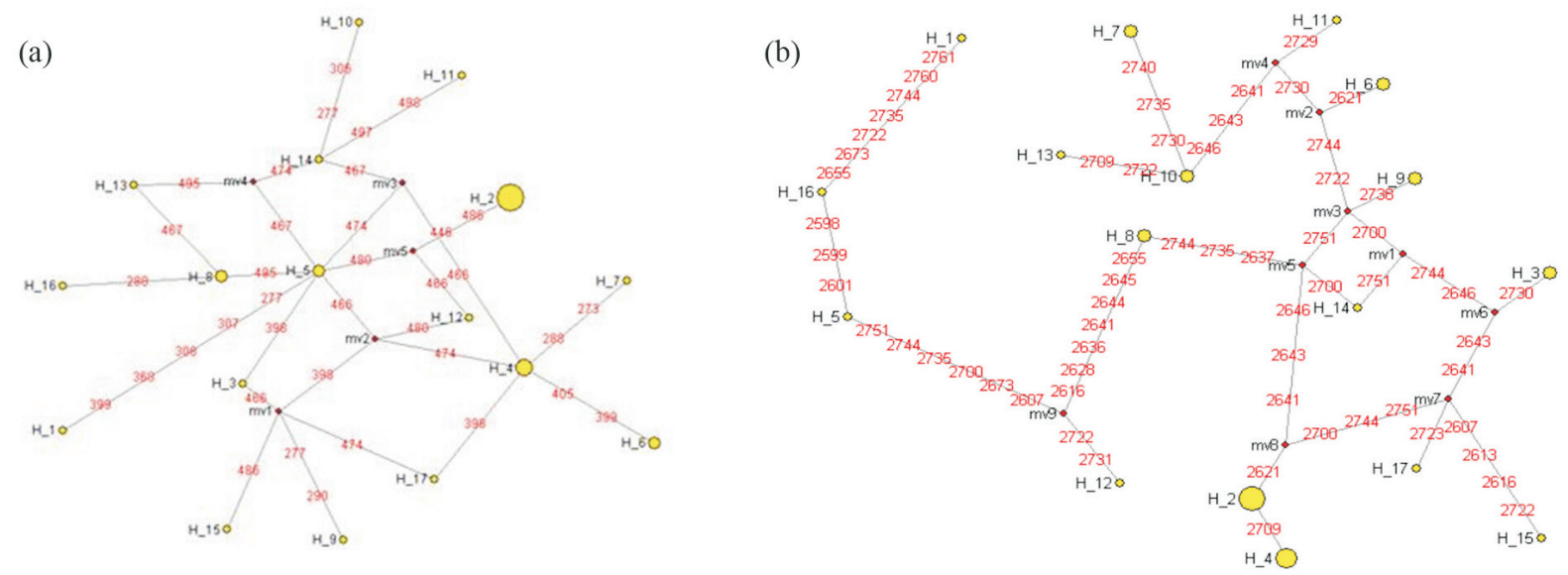

(c)

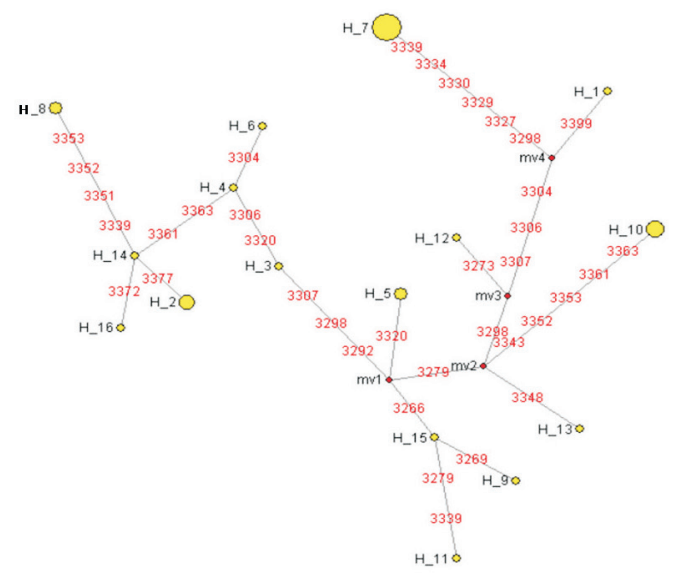

Figure S2 - Deduced amino acid sequence of partial cagA gene of $H$. pylori showing (a) tyrosine phosphorylation motif A (TPM A), (b) tyrosine phosphorylation motif B (TPM B), and (c) tyrosine phosphorylation motif C (TPM C). 